\title{
Importance of Practical Courses for a Professional Degree: A Case of Library \& Information Science (LIS)
}

\author{
Farhat Hussain \\ Assistant Professor \\ Department of library and Information Science, University of Karachi \\ Munira Nasreen Ansari \\ Associate Professor \\ Department of library and Information Science, University of Karachi
}

\begin{abstract}
The purpose of this study is to seek the opinion of Pakistani library professionals employed in different types of libraries and organizations about importance of practical courses, theory courses and practical-cum-theory courses they had studied for the fulfillment of their professional degree. It is a survey research based on a structured questionnaire. The survey reveals that the library schools of Pakistan design and develop their courses of their own accord to fulfill the local needs but they also follow the curriculum designed by the Higher Education Commission (HEC). While designing curricula, the international standard and uniformity is taken into consideration and the core courses to be taught in the first year of Masters program remain more or less same in all library schools. The theory and practical courses are also the part of curricula and imparting practical education is given due consideration. The professionals identified some courses in which more practical factor should be included so that the graduates should not face problems after joining the professional field.
\end{abstract}

Keywords: LIS education; Practical Courses; Theory-Practical Ratio; Curriculum; Pakistan; Curriculum Development

DOI: $10.7176 / \mathrm{JESD} / 10-8-20$

Publication date: April $30^{\text {th }} 2019$

\section{Introduction}

To meet the varying needs of the environment, the emphasis of LIS education has been laid on producing capable and competent manpower. History of librarianship and library education has seen a number of developmental changes from 1887 (when first library school was established in United States by the originator of Dewey Decimal Classification Scheme, Melvil Dewey) to date. During this period, the significance of courses of studies has been realized for the present-day information atmosphere, with more importance and weightage given to LIS curriculum than traineeship. LIS academicians realize the need of up-to-date curriculum that produces professionals compatible with the changing information arena. The varying job market of information and library professionals demands new proficiencies in LIS graduates to augment employability. Curriculum models contain the designing and the actions, the resources' support and the examination required. They are primarily layout to give undeviating educational methods and anticipated outcomes of students. The level of flexibility in curriculum models varies that is provided to educators. Few curriculum models provide teachers a detailed script to proceed while others outline the principles providing an open path to make the best use of these principles over the students. Even some schools modify these curriculum models as per the needs and trends of local market.

In the present times, the importance of libraries and librarians has assumed high priority. In the West, the opportunity in business community, suggest a boost in professional status of Library and Information Science. Separate distinct positions of library professionals in corporate and business libraries are created under some attractive titles like Information Manager, Chief Information Officer or Knowledge Officer. However, the information's success depends upon the selection and analysis of information to meet the desired needs of the organization. Here the effectiveness of Library and Information Science could play its important role. The skills of the librarians can help the employees saving their valuable time on activities; as Internet surfing, information access and acquisition of previous information on the subject. Realizing the value of Library \& Information Science, many universities in almost every country are offering it as a part of their curricula.

\section{Objective}

This study strives to analyze and evaluate the practical training being imparted to the learners by different library schools of Pakistan. It also endeavors to find out the nature of the courses as theory- or practical-based and their implementation in the profession. To meet the target, the study is:

- To investigate how much the theory courses are implemented in the profession.

- To investigate how much the practical courses are implemented in the profession.

- To know how much the respondents are satisfied with the theory-practical ratio of the courses. 
- To inquire the respondents about utilization of practical training in the field.

- To strive for recommendations about needed practical training.

\section{Literature Review}

Browsing of the literature reveals that much has been written on every aspect of library education, LIS curricula, qualification and competencies required for library professionals, importance of practical training in LIS profession etc. Suggestions have also been given to improve the abilities and proficiencies of the library professionals and to incorporate these recommendations in the curricula for better production of LIS graduates. A case study was carried out to reveal the value of LIS practicum in attaining numerous professional skills from the views of LIS graduates. Malik and Ameen, (2010). The study suggested that resourceful and well-coordinated curriculum is important in reforming professional skills. For data collection, multiple techniques of data collection were used, i.e. a survey-based questionnaire (having both closed and open ended questions), discussions and interviewing of senior faculty and keen observation is done (as a participant observer) to investigate the true status. LIS graduates of Punjab University sessions 2002-2006 were identified as the population. Total population was 367 and the targeted sample was 118 graduates. While the technique used to reach them was Snowball sampling technique. The authors suggested that as it was a practicum of LIS it must be of practitioner's interest. The findings reveal that the practicum duration was insufficient, there was gap in communication among the three parties i.e. students, external and internal supervisor, slake supervision and scarce attention on professional skills are the problems reported by LIS graduates. Moreover, the findings will be helpful in creating effective and convincing practicum programs of LIS in Pakistan and other developing states.

Shahid and Singh (2010) highlighting the problems and shortcomings of LIS education in India, observe there is shortage of staff and lack of expertise in ICT. It is also found that the LIS professionals lack ICT skills and face problems in the job market. Due to the same reason, most of the employers are not satisfied with the skills of information professionals. The authors recommend monitoring and revision of curricula on regular basis and suggest a statutory body to accredit programs according to international standard. UGC must appoint review committees to regularly take stock of the situation in the LIS curriculum.

Ullah, Ameen and Bakhtar (2010) identify the required competencies, professional activities, education as well as training needs and demands of medical librarians in Pakistan. They studied the contemporary concerns of medical professionals in Pakistan, the ideology for the medical librarians along with their required competencies, and their practical trainings and educational needs. Purposive sampling was used to assess twenty medical librarians. After an expert's review and pilot testing a verbal questioning guide was prepared. Through personal visits and telephonic interviews the data got collected. It was revealed from the findings that traditional professional activities are the major concern of medical librarians who are unfamiliar with the new developments in medical librarianship. From all competencies only these were ranked first, second and third respectively, mentioned; "ability to use ICT and integrated library software", "verbal and written communication skills" and "extensive knowledge of Pub Med (a free search engine that provides access chiefly to the MEDLINE database of references and abstracts on life sciences, biomedical and relevant topics) and other medical databases". It was assessed that medical librarians get limited opportunities of enhancing their further education and training. Based on the discovered facts of this study it was suggested that post-master (MLIS) specialized diploma in medical librarianship and future training and upgrading programs should be introduced for medical librarians in Pakistan by MELAP (Medical Library Association of Pakistan), CPSP (College of Physicians and Surgeons Pakistan) and library schools.

Mahmood, and Khan (2007) assessed the continuing education (CE) required for LIS Professionals' ICT skills or techniques. The authors are of the view that the results of their study will help the library schools and professional associations and will support in the preparation of LIS professionals for creating control and command in this digital age even beyond the boundaries of their nation. As today, awareness and capabilities of usability of application of ICTs is one of the greatest expectations over LIS professionals, there seems a dearth between the traditional knowledge-based skills and modern competency of ICTs that is needed to get fulfilled. The researchers, through their research, found that the training of ICT can be provided through courses and workshops, hands-on practices, visits of other institutions, professional meetings, seminar/conferences, series of lectures, telephonic/video conferencing etc. The findings of the research reveal that the arrangement of all the trainings and know-how about ICT should be made by the professional associations, library schools, employers and ICT vendors.

Haider (2006) analyzes six LIS Departments of the country with respect to their cataloging and classification courses' contents and teaching methodologies. As both of these courses are regarded as the core courses of library science with almost equal theory and practical ratio and provide a foundation of librarianship, these are the integral part of the curricula at all academic levels of library education in Pakistan. The study reveals that in almost all library schools of the country, cataloging practices of the 1960s and 1970s dominate and it has not been modified. Moreover, there is an absence of latest technologies, deficiency of competent teachers, disappointing conditions of lab facilities in terms of equipment and library materials. Same is the situation of classification practices. There 
is a severe scarcity of DDC (Dewey Decimal Classification) and LCC (Library of Congress Classification) schedules. Although latest edition of DDC is purchased but only 8-10 sets are acquired due to shortage of financial resources. Students do practice in groups and 2-3 students share one set of the schedule. Suggestions comprise: curricula revision, organizing training of teachers for cataloging and classification courses in developed countries, improvement of laboratories, and the organization of continuing education programs.

Mahmood (2003) describes the literature present on the required competencies of academic librarians in the Asia/Pacific region and discusses the academic librarianship in Pakistan with respect to its circumstances, providing skills required for entry-level librarians at academic level, designed with the help of reviewed literature and crossed by 70 chief librarians belonging to public and private universities and postgraduate colleges which was then matched with the LIS programs' curricula. It also highlighted the major weaknesses of curricula and mentioned ways to implement and recommend for the betterment. Curriculum development has not been taken seriously in library schools, the practitioners criticize the curriculum as outdated and irrelevant. Some important courses are not included e.g. Knowledge Management, Change Management, Resource Development Skills. Some referencing skills and digital competencies carry less importance in the practicing curricula. Also scheming webbased material and utilization of digital technologies are not incorporated by any library school, except one, that offers the practical approach of curriculum for its students.

Mahmood and Sharif (2001) in a study inquired respondents (i.e. Alumni, Pakistan Library Association's Computer Training Center in Lahore), in order to identify the affects occurred by the CLA (Certificate in Library Automation) on the librarianship of Pakistan. While the results disclose that young professional librarians especially those who are working in Lahore majorly attended the course. The respondents revealed that their computer training was very much helpful for them for switching over to better job positions. Many of them avail computer facilities at their workplace and exercise a regular use and also participate in activities regarding automation in libraries. Majority of the respondents revealed that their knowledge of computer is applied at writing articles and books, lecture delivering and in provision of consultancy services.

Library \& Information Science education has developed to a large extent during the last two decades of $20^{\text {th }}$ century and this journey is still continued in $21^{\text {st }}$ century all over the world. The introduction of modern information technology and the associated concepts of digitization, automation, virtualization, mechanization, computerization etc. have accelerated the change in the services and organization of libraries. In the developed countries and continents like Europe, America and Canada, remarkable development has been witnessed in LIS education during the last three decades. Plans have been chalked out to cope with the challenges of globalization and internationalization. For this purpose, major and drastic changes have been brought out not only in the education but also in the curricula of library and information science and all this is to revolutionize the schemes of studies for competing the global employment market. These competencies are associated with the research skills, IT skills, online and networking skills. The curricula also incorporate the changes occurred in library organization and services from traditional set up to digital form.

\section{Methodology}

Data about the importance of practical courses offered at Masters level by the library schools of Pakistan and implementation of these courses in the professional field was collected through questionnaires filled by the library professionals working in different types of libraries of all the provinces, Azad Kashmir, FATA, and federal capital Islamabad. On the basis of literature review and discussion with some eminent library educationists and senior professionals, a structured questionnaire was designed to obtain required data.

The questionnaire was composed of following parts:

a) Demographic: It intends to seek information about the name (optional), designation, organization, type of library working in, working experience, name of the university studied in, highest professional degree obtained, and year of passing of the respondents.

b) Classified: It contains: i. Questions based on level of measurement ii. Dichotomous questions and iii. Openended questions

The population to respond the questions was identified as all library professionals working in different types of libraries (including academic, school, national, public, and special) but holding necessarily a postgraduate library science degree. The respondents had been graduated from any university of Pakistan irrespective of the year of passing as opinions of professionals from junior most to senior were intended to be attained. After contacting the respondents, questionnaires were sent by e-mail, by surface mail and by personal visits. To remove any ambiguity or confusion, the questions were also explained on phone or personally to the respondents. Although the population was randomly selected but the following points were taken into consideration:

a) Graduates of all the library schools should be approached

b) Working librarians of all the provinces and federal capital should be covered

c) Library professionals working in all types of libraries should be contacted

d) Professionals should be the representatives of all age groups ranging from 25 to 60 
e) They should have different working experience.

A total 300 questionnaires were distributed among the professionals of all four provinces and federal capital. Of them, 250 questionnaires were received back and it was a rigorous exercise to remind and pursue the respondents.

Besides demographic information, the other information sought from the participants were opinion about usefulness and utilization and non-utilization of practical training in the profession, implementation or nonimplementation of theory courses in the profession, importance of modern communication and information technology in the field, views about theory-practical ratio of the courses offered by library schools. They were also asked to identify the courses in which practical training is necessary but is not imparted presently in any or all the library schools.

The data of questionnaires were statistically analyzed using SPSS (Statistical Package for the Social Science) computer software. Various statistical procedures used in the data analysis include Frequency distribution, and Descriptive statistics.

\section{Data Analysis and Interpretation}

Following is the analysis and interpretation of the data collected through questionnaire:

\section{Demographic Characteristics}

The targeted population of the ongoing research is library professionals working in different types of libraries in Pakistan covering all four provinces and federal capital Islamabad.

Table 1 : Demographic characteristics of the participants

\begin{tabular}{|l|l|l|}
\hline Characteristics (Age) & Frequency $(\mathbf{N}=250)$ & Percentage \\
\hline Less than 31 years & 51 & 20.4 \\
\hline Between 31 and 40 years & 134 & 53.6 \\
\hline 41 years and above & 65 & $\mathbf{2 6 . 0}$ \\
\hline Characteristics (Gender) & Frequency $(\mathbf{N}=250)$ & Percentage \\
\hline Male & 166 & 66.4 \\
\hline Female & $\mathbf{8 4}$ & $\mathbf{3 3 . 6}$ \\
\hline
\end{tabular}

A total 250 filled questionnaires were received from library professionals across Pakistan. Of these, 166 respondents $(66.4 \%)$ were male and $84(33.6 \%)$ were female. With respect to their age, three categories were formed: those who were less than 31 years of age were $51(20.4 \%)$, the age group between 31 and 40 was composed of 134 respondents $(53.6 \%)$ and this is the largest group whereas those who were more than 40 years of age were $65(26.0 \%)$.

Name of Degree Awarding Province/Federal Capital

There are one or more library schools in all the four provinces and federal capital Islamabad. These schools professionally train the librarians and award them degrees from postgraduate to doctorate level. The professionals rendering their services in the libraries at home or abroad are the graduates of these schools.

Table 2: Province of obtaining professional degree

\begin{tabular}{|l|l|l|}
\hline \multicolumn{2}{|l|}{} \\
\hline Professional Degree acquired from: & Frequency $(\mathbf{N}=\mathbf{2 5 0})$ & Percentage \\
\hline Punjab & 97 & 38.8 \\
\hline KPK & 67 & 26.8 \\
\hline Sindh & 46 & 18.4 \\
\hline Federal capital, Islamabad & 24 & 9.6 \\
\hline Baluchistan & 16 & 6.4 \\
\hline
\end{tabular}

The universities from where the respondents got professional degrees are located in all four provinces, and federal capital, Islamabad. Of them, 97 (38.8\%) belonged to Punjab, 67 (26.8\%) from Khyber PakhtoonKhawah, 46 (18.4\%) belonged to Sindh, 24 (9.6\%) represented Islamabad, and remaining 16 (6.4\%) from Baluchistan. Although they got their professional education from the universities of above four provinces and federal capital but they are working in a different or same area.

\section{Highest Professional Degree obtained}

All the professionals working in different capacities and positions, are holding degrees from Masters to Doctorate. The following table shows the highest degree they have obtained: 
Table 3: Professional Degree obtained by the respondents

\begin{tabular}{|l|l|l|}
\hline Highest Professional Degree & Frequency $(\mathbf{N}=\mathbf{2 5 0})$ & Percentage \\
\hline MLIS & 169 & 67.6 \\
\hline MLS & 27 & 10.8 \\
\hline MS & 18 & 7.2 \\
\hline M.Phil & 24 & 9.6 \\
\hline Ph.D & 12 & 4.8 \\
\hline
\end{tabular}

The highest degree the respondents acquired included: MLS, MLIS, MS (in Lib \& Inf. Sc.), M.Phil. (LIS), and Ph.D. (LIS). Although MLS and MLIS are the same level degrees but those who passed out before 1980-85, hold the degree of MLS whereas the rest is possessing MLIS. 169 respondents $(67.6 \%)$ have MLIS degree, 27 respondents (10.8\%) hold MLS degree, $18(7.2 \%)$ are MS (LIS) degree holders, 24 respondents (9.6\%) hold M.Phil. degree whereas only 12 (4.8\%) are holding Ph.D. (LIS) degree.

\section{Type of Library of the participants}

Primarily, there are four types of library viz. academic, national, public, and special. The graduates of library schools are providing professional services in all types of library.

Table 4: Type of Library the participants working in

\begin{tabular}{|l|l|l|}
\hline Type of Library & Frequency $(\mathbf{N}=\mathbf{2 5 0})$ & Percentage \\
\hline Academic & 130 & 52.0 \\
\hline Special & 59 & 23.6 \\
\hline Public & 42 & 16.8 \\
\hline National & 19 & 7.6 \\
\hline
\end{tabular}

As far as the type of library is concerned, most of the respondents are working in academic libraries. A total $130(52.0 \%)$ respondents belong to academic libraries, 59 (23.6\%) from different special libraries, 42 (16.8\%) respondents are from public libraries, and 19 (7.6\%) from National Library of Pakistan.

\section{Working Experience}

As the targeted population of this research comprises all library professionals irrespective of their professional experience, from junior most to senior most working professionals took part. Following four categories were developed to show the years of their involvement in the profession.

Table 5: Working experience of the respondents

\begin{tabular}{|l|l|l|}
\hline Working Experience & Frequency $(\mathbf{N}=\mathbf{2 5 0})$ & Percentage \\
\hline 1 - 5 years & 53 & 21.2 \\
\hline 6 - 10 years & 90 & 36.0 \\
\hline $11-15$ years & 48 & 19.2 \\
\hline$>15$ years & 59 & 23.6 \\
\hline
\end{tabular}

The targeted population was composed of professionals having working experience of different years. This experience has been categorized into: 1-5 years, 6-10 years, 11-15 years and more than 15 years. There were 53 participants $(21.2 \%)$ having experience of $1-5$ years and they were comparatively young professionals working at junior positions. In the category of 6-10 years of experience, the number of participants was $90(36.0 \%)$. Professionals with relatively plentiful experience and senior position, had working experience from 11-15 years and among the total participants of the study, their number was $48(19.2 \%)$. Those who fall in the last category of more than 15 years of experience were working at the positions of senior librarian, chief librarian or head of the department. They had a vast professional experience and were well-versed with all the activities and functions of a library. The number of such respondents was $59(23.6 \%)$.

\section{Implementation of theory courses in profession}

In a practical and professional discipline, the courses are designed in such a way that they are either fully or partially implemented in the field. The majority of the courses taught at postgraduate level in all the library schools are composed of theory and practical. The practical training of any course is, no doubt, applied in the profession but to strengthen the professional knowledge and to understand the philosophy of the subject, theory courses also deserve equal importance. Without apprehending and grasping the subject matter and exhibiting command on the roots of the text, better professional services cannot be rendered. To get the viewpoint of the respondents about the usefulness of the theory courses they studied during their university, they were asked to prioritize All, Some, or None of the courses: 
Table 6 : Implementation of the theory courses in profession

\begin{tabular}{|l|l|l|}
\hline $\begin{array}{l}\text { Usefulness of theory courses in professional } \\
\text { career }\end{array}$ & Frequency $(\mathbf{N}=\mathbf{2 5 0})$ & Percentage \\
\hline All & 82 & $\mathbf{3 2 . 8}$ \\
\hline Some & 155 & $\mathbf{6 2 . 0}$ \\
\hline None & 13 & 5.2 \\
\hline
\end{tabular}

Regarding the usefulness of the theory courses studied at postgraduate level for the professional career, 82 respondents (32.8\%) replied for all the courses, $155(62.0 \%)$ replied for some of the courses, and only $13(5.2 \%)$ respondents replied for none of the courses.

\section{Usefulness of the practical courses}

There is a list of courses which are partially or wholly based on practical work. Some of such courses are classification, cataloguing, bibliography, reference sources and services, library operations, information and communication technology, digital library etc. The viewpoint of the respondents about the usefulness of practical of these courses is diversified.

Table 7(A): Usefulness of the practical courses

\begin{tabular}{|c|c|c|}
\hline Usefulness of the practical of classification in profession & Frequency $(\mathrm{N}=\mathbf{2 5 0})$ & Percentage \\
\hline Highly Useful & 115 & 46.0 \\
\hline Useful & 120 & 48.0 \\
\hline Somewhat Useful & 15 & 6.0 \\
\hline Usefulness of the practical of cataloguing in profession & Frequency $(\mathrm{N}=\mathbf{2 5 0})$ & Percentage \\
\hline Highly Useful & 100 & 40.0 \\
\hline Useful & 116 & 46.4 \\
\hline Somewhat Useful & 34 & 13.6 \\
\hline $\begin{array}{l}\text { Usefulness of the practical of Reference Sources and Services } \\
\text { in profession }\end{array}$ & Frequency $(\mathrm{N}=\mathbf{2 5 0})$ & Percentage \\
\hline Highly Useful & 115 & 46.0 \\
\hline Useful & 108 & 43.2 \\
\hline Somewhat Useful & 27 & 10.8 \\
\hline
\end{tabular}

Classification is a core subject of librarianship and is taught in all library schools. As regards the usefulness of classification practical in the job, $115(46.0 \%)$ respondents were of the view that it is highly useful, $120(48.0 \%)$ opined that it is useful whereas only $15(6.0 \%)$ respondents termed it somewhat useful. When the same question of usefulness of cataloguing practical in the profession was asked, almost the similar ratio of responses was received. $100(40 \%)$ of total respondents replied that it is highly useful, $116(46.4 \%)$ declared the course useful however $34(13.6 \%)$ respondents proclaimed the course as somewhat useful. Reference Sources and Services is also another useful course which is considered as the backbone of librarianship. About realizing the usefulness of the practical of the course, $115(46.0 \%)$ participants termed it highly useful, 108 respondents $(43.2 \%)$ identified it as useful while the remaining $27(10.8 \%)$ observed that it is somewhat useful.

Table 7(B): Usefulness of the practical courses

\begin{tabular}{|l|l|l|}
\hline Usefulness of the practical of bibliography in profession & Frequency $(\mathbf{N}=\mathbf{2 5 0})$ & Percentage \\
\hline Highly Useful & 54 & 21.6 \\
\hline Useful & 128 & 51.2 \\
\hline Somewhat Useful & 68 & 27.2 \\
\hline Usefulness of the practical of library operation in profession & Frequency $(\mathbf{N}=\mathbf{2 5 0})$ & Percentage \\
\hline Highly Useful & 112 & 44.8 \\
\hline Useful & 123 & 49.2 \\
\hline Somewhat Useful & 15 & $\mathbf{6 . 0}$ \\
\hline Usefulness of practical of ICT/ Digital Libraries in profession & Frequency $(\mathbf{N}=\mathbf{2 5 0})$ & Percentage \\
\hline Highly Useful & 122 & 48.8 \\
\hline Useful & 106 & 42.4 \\
\hline Somewhat Useful & 22 & $\mathbf{8 . 8}$ \\
\hline
\end{tabular}

When the opinion of respondents with respect to usefulness of practical training of the course of Bibliography was sought, only $54(21.6 \%)$ declared it highly useful, 128 respondents $(51.2 \%)$ termed it useful whereas 68 $(27.2 \%)$ respondents considered it somewhat useful. The course of Library Operations covers almost all the pursuits and professional activities performed in a library. Practical training is also the part of this course. When inquired about the usefulness of practical training of this course in the job, 112 (44.8\%) respondents called it highly useful, 123 respondents (49.2\%) named it useful and the rest $15(6.0 \%)$ respondents labeled it somewhat useful. In respect of same question about the usefulness of practical of ICT/Digital Libraries in the job, 122 (48.8\%) 
respondents termed it highly suitable, $106(42.4 \%)$ dubbed it useful while the remaining $22(8.8 \%)$ designated it somewhat useful.

\section{Utilization of Practical Training in the field}

A variety of responses were received about the implementation of practical training in the profession. The respondents (total number 250) identified total 644 either titles of courses or parts of courses which they had studied under different courses. The respondents had their own choice to give as many as possible number of titles. The frequencies of their responses are calculated in two ways; out of total identified titles and out of total respondents.

Table 8: Implementation of courses studied in practical field (Profession)

\begin{tabular}{|l|l|l|l|}
\hline $\begin{array}{l}\text { Title of Training/ Courses } \\
\text { Studied }\end{array}$ & $\begin{array}{l}\text { Responses } \\
(\mathbf{N = 6 4 4 )}\end{array}$ & $\begin{array}{l}\text { Percent (Out } \\
\text { of N) }\end{array}$ & $\begin{array}{l}\text { Percent of Cases (out of total } \\
\text { Respondents) }\end{array}$ \\
\hline Automation/Software./ICT & 103 & 15.9 & 41.2 \\
\hline Report Writing & 93 & 14.4 & 37.2 \\
\hline Project Management & 92 & 14.3 & 36.8 \\
\hline Account Management & 91 & 14.1 & 36.4 \\
\hline Business Communication & 89 & 13.8 & 35.6 \\
\hline Classification (DDC) & 56 & 8.7 & 22.4 \\
\hline Book Material Cataloging & 33 & 5.1 & 13.2 \\
\hline Library Management & 14 & 2.1 & 5.6 \\
\hline KOHA & 13 & 2.0 & 5.2 \\
\hline Bibliography & 10 & 1.6 & 4.0 \\
\hline Reference Services & 10 & 1.6 & 4.0 \\
\hline Classification (LC) & 9 & 1.3 & 3.6 \\
\hline Internship & 8 & 1.2 & 3.2 \\
\hline Indexing & 6 & 0.9 & 2.4 \\
\hline Sp. Material Cataloguing & 6 & 0.9 & 2.4 \\
\hline LIMS & 5 & 0.7 & 2.0 \\
\hline WINISIS & 4 & 0.6 & 1.6 \\
\hline Archive Management & 2 & 0.3 & 0.8 \\
\hline
\end{tabular}

The maximum responses were given for relevant topics like library automation, software, software training, digitization, information and communication technology etc. These were 103 out of total 644 responses which were $15.9 \%$ of total responses and $41.2 \%$ of total target population. The other outstanding responses (93 out of total 644) were for Report Writing, 92 for Project Management, 91 for Account Management, and 89 for Business Communication. These responses are respectively $14.4 \%, 14.3 \%, 14.1 \%$, and $13.8 \%$ of the total responses and $37.2 \%, 36.8 \%, 36.4 \%$, and $35.6 \%$ of the target population responded for the practical trainings of these courses or part of courses which is being applied in their profession.

Then the next maximum responses were received respectively for Classification (DDC) and Cataloguing of book material. For Classification there were 56 responses $(8.7 \%)$ and for Cataloguing $33(5.1 \%)$. The responses indicate that for $22.4 \%$ respondents, the learning and training of Classification is being applied in their profession whereas $13.2 \%$ of respondents are applying training of Cataloguing at their work. The application of other remarkable trainings in the profession is of Library Management (2.1\%), KOHA (2.0\%), and Reference Services $(1.6 \%)$, and Bibliography $(1.6 \%)$.

\section{Non-Application of Practical Training in Profession}

The opinions about non-application of practical training in the profession, diversified responses were received. The respondents (total number 250) identified total 588 either titles of courses or parts of courses which they had studied under different courses. The respondents had their own choice to give as many as possible number of titles. The frequencies of their responses are calculated in two ways; out of total identified titles and out of total respondents. 
Table 9 : Non-Implementation of courses in practical field (Profession)

\begin{tabular}{|l|l|l|l|}
\hline $\begin{array}{l}\text { Title of Training/ Courses } \\
\text { studied }\end{array}$ & $\begin{array}{l}\text { Responses } \\
(\mathbf{N = 5 8 8})\end{array}$ & $\begin{array}{l}\text { Percent } \\
\text { (Out of N) }\end{array}$ & $\begin{array}{l}\text { Percent of Cases } \\
\text { Respondents) }\end{array}$ \\
\hline Indexing & 175 & 29.7 & 70.0 \\
\hline History of Books \& Libraries & 172 & 29.2 & 68.8 \\
\hline Abstracting & 171 & 29.1 & 68.4 \\
\hline Library Automation & 14 & 2.4 & 5.6 \\
\hline Information Technology & 11 & 1.8 & 4.4 \\
\hline Cataloging/AACR & 7 & 1.2 & 2.8 \\
\hline LC Classification & 5 & 0.8 & 2.0 \\
\hline LC Subject Headings & 5 & 0.8 & 2.0 \\
\hline Library Software & 4 & 0.7 & 1.7 \\
\hline RDA & 4 & 0.7 & 1.7 \\
\hline Bibliography & 3 & 0.5 & 1.2 \\
\hline MARC & 3 & 0.5 & 1.2 \\
\hline Networking & 3 & 0.5 & 1.2 \\
\hline Project Management & 3 & 0.5 & 1.2 \\
\hline Presentation Skill & 2 & 0.3 & 0.8 \\
\hline Marketing of Library Services & 2 & 0.3 & 0.8 \\
\hline Account Management & 2 & 0.3 & 0.8 \\
\hline Digital Library & 2 & 0.3 & 0.8 \\
\hline
\end{tabular}

The maximum responses for non-application of courses in the profession are received for Indexing (175 responses out of total 588). This comes to $29.7 \%$ of the responses whereas $70.0 \%$ of the respondents. The other courses are Abstracting for which 171 (29.1\%) responses were received from $68.4 \%$ of respondents, and History of Books and Libraries for which 172 (29.2\%) responses were received from $68.8 \%$ of the respondents. The other notable responses are for Library Automation (2.4\% from 5.6\% population), Information Technology (1.8\% from $4.4 \%$ population) and Cataloguing ( $1.2 \%$ from $2.8 \%$ population). Rest of all title of courses/training is inconsiderable.

\section{Satisfaction with theory-practical ratio}

As the curricula of all the universities comprise theory-based, practical-based, and theory-cum-practical-based courses. The curricula seem to be balanced with respect to theory-practical ratio:

Table 10: Satisfaction with theory-practical ratio

\begin{tabular}{|l|l|l|}
\hline $\begin{array}{l}\text { Satisfaction with the theory/ } \\
\text { practical ratio of the courses }\end{array}$ & Frequency $(\mathbf{N}=\mathbf{2 5 0})$ & Percentage \\
\hline No & $\mathbf{1 2}$ & $\mathbf{4 . 8}$ \\
\hline Yes & $\mathbf{2 3 8}$ & $\mathbf{9 5 . 2}$ \\
\hline
\end{tabular}

Only $12(4.8 \%)$ respondents are dissatisfied with the ratio whereas majority 238 (95.2\%) participants expressed their satisfaction with the theory-practical ratio.

\section{Theory-based courses and Practical-based courses}

There are some courses which are only theory-based and some courses which are practical-based and all the universities are treating them as per their nature. Opinion of the professionals was sought to identify such courses which are against their nature:

Table 11: Satisfaction with theory-based and practical-based courses

\begin{tabular}{|l|l|l|}
\hline $\begin{array}{l}\text { Opinion about the courses to be based } \\
\text { on only theory work }\end{array}$ & Frequency $(\mathbf{N}=\mathbf{2 5 0})$ & Percentage \\
\hline No & $\mathbf{2 2 4}$ & $\mathbf{8 9 . 6}$ \\
\hline Yes & $\mathbf{2 6}$ & $\mathbf{1 0 . 4}$ \\
\hline $\begin{array}{l}\text { Opinion about the courses to be based } \\
\text { on only practical work }\end{array}$ & Frequency $(\mathbf{N}=\mathbf{2 5 0})$ & Percentage \\
\hline No & $\mathbf{1 9 4}$ & $\mathbf{7 7 . 6}$ \\
\hline Yes & $\mathbf{5 6}$ & $\mathbf{2 2 . 4}$ \\
\hline
\end{tabular}

Majority of the respondents was satisfied with the existing set-up but there were few who gave their contrary opinion. About courses to be based on only theory, only $26(10.4 \%)$ respondents replied in affirmative while 224 $(89.6 \%)$ negatively replied. Similarly, opinion of $56(22.4 \%)$ respondents was in favour of only practical work courses whereas $194(77.6 \%)$ respondents were against. 


\section{Recommendations about needed practical training}

In a number of courses, practical training is integral part and students are involved in hands-on practice to get the maximum output of their studies. The participants were asked to give their feedback if they still need any practical training in some areas which are ignored in the curricula of universities of the country. In all 229 titles were identified by the total population (250). The frequencies of their responses are calculated out of total identified titles and out of total respondents:

Table 12: Recommendations for needed practical training

\begin{tabular}{|c|c|c|c|}
\hline Characteristics & Frequency $(\mathrm{N}=229)$ & Percentage & $\begin{array}{l}\text { Percent of cases } \\
\text { (out of total respondents) }\end{array}$ \\
\hline ICT & 59 & $25.9 \%$ & 23.6 \\
\hline Open Source Software Technology & 25 & $11.0 \%$ & $\mathbf{1 0 . 0}$ \\
\hline Management Skill & 21 & $9.2 \%$ & 8.4 \\
\hline Library Automation & 18 & $7.9 \%$ & 7.2 \\
\hline Development of Digital Library & 15 & $6.6 \%$ & 6.0 \\
\hline Classification & 9 & $3.9 \%$ & 3.6 \\
\hline Communication Skill & 9 & $3.9 \%$ & 3.6 \\
\hline Cataloguing & 8 & $3.5 \%$ & 3.2 \\
\hline Information Literacy & 8 & $3.5 \%$ & 3.2 \\
\hline Archival Management & 7 & $3.1 \%$ & 2.8 \\
\hline Database Development & 6 & $2.6 \%$ & 2.4 \\
\hline Web Development & 6 & $2.6 \%$ & 2.4 \\
\hline Personality Grooming & 5 & $2.2 \%$ & 2.0 \\
\hline User Psychology & 5 & $2.2 \%$ & 2.0 \\
\hline Information Management & 4 & $1.8 \%$ & 1.6 \\
\hline Leadership Skills & 3 & $1.3 \%$ & 1.2 \\
\hline Customer Service & 2 & $0.9 \%$ & 0.8 \\
\hline Internship & 2 & $0.9 \%$ & 0.8 \\
\hline Knowledge Management & 2 & $0.9 \%$ & 0.8 \\
\hline Library Correspondence & 2 & $0.9 \%$ & 0.8 \\
\hline Marketing of Library Services & 2 & $0.9 \%$ & 0.8 \\
\hline MARC & 2 & $0.9 \%$ & 0.8 \\
\hline RDA & 2 & $0.9 \%$ & 0.8 \\
\hline Data Mining and Filtering & 1 & $0.4 \%$ & 0.4 \\
\hline Event Management & 1 & $0.4 \%$ & 0.4 \\
\hline Information Storage & 1 & $0.4 \%$ & 0.4 \\
\hline Professional Writing & 1 & $0.4 \%$ & 0.4 \\
\hline Social Media & 1 & $0.4 \%$ & 0.4 \\
\hline Reference Services & 1 & $0.4 \%$ & 0.4 \\
\hline
\end{tabular}

Recommendations of the participants were sought about the practical training(s) in librarianship in the course(s) which they deem necessary but not imparted in any university of Pakistan. A variety of subjects and courses were detected by the respondents but a number of the courses were wrongly identified as some or all the library schools are giving their practical trainings. Majority of the responses 59 (25.9\% of total responses) were for ICT and $23.6 \%$ respondents identified the course. Open source software technology got $25(11.0 \%)$ responses by $10.0 \%$ respondents. $21(9.2 \%)$ responses are for Management Skills identified by $8.4 \%$ population. 18 (7.9\%) responses are identified for Library Automation by 7.2\% participants. The course of Development of Digital Library received $15(6.6 \%)$ responses by $7.2 \%$ respondents. Classification $9(3.9 \%)$, Cataloguing $8(3.5 \%)$, and Information Literacy $8(3.5 \%)$ were other notable courses identified respectively by $3.6 \%, 3.2 \%$, and $3.2 \%$ respondents. $7(3.1 \%)$ responses are for Archival Management identified by $2.8 \%$ participants, whereas Web Development and Database Development both got $6(2.6 \%)$ responses each by $2.4 \%$ respondents. The remaining identified courses are inconsiderable.

\section{Key Findings}

- Majority of the respondents declared some of the theory courses are useful for professional career.

- Majority of the participants declared usefulness of practical of Classification, Cataloguing, Reference Sources and Services, Library Operations, ICT/Digital Library, Library Automation, Software, Software Training, Digitization, etc. in profession.

- Majority was satisfied with Theory-Practical ratio of the courses. 
- Majority declared the courses of Indexing, and Abstracting as the courses of non-application in the practical field.

- Majority of the respondents was satisfied with the existing set-up of theory-based and practical-based courses offered by all library schools of Pakistan.

- Some of the identified courses recommended by the participants in which practical training is needed include: ICT, Open Source Software Technology, Management Skills, Library Automation, and Development of Digital Library.

\section{Discussion}

The survey reveals that the professionals who had done their Masters more than 15 years ago and are working in one or another type of library, deem the courses they had studied incompatible with the modern requirements. According to them, at that time the courses were more theoretical and a very small fraction of the courses was practical one except the courses of technical section like classification, cataloguing, indexing, abstracting, bibliography etc. They were of the view that due to a little trend towards automation and computerization in libraries at that time, the library schools were also lacking in the relevant courses.

The professionals who have got opportunity of applying their knowledge of practical of a course or another in their profession, consider it suitable and those who have not got a chance, deem it unsuitable or useless. They recommended to include more practical work in some of the existing courses and to introduce some new courses which should be compatible with the ongoing demands. Even though practice of all the courses is applied in the professional field but the most important courses with respect to application and usefulness of their practical are classification, library operations, ICT/digital libraries. The courses which come at the second place in this regard are cataloguing, reference sources and services, bibliography etc.

The courses which were identified to have only practical work include Digital Library Development, Classification, Cataloguing, Reference Services, Information Retrieval, Bibliography. The results of the survey about practical courses the respondents studied are hopeful but they also recommended some more practical work in identified courses. Although the practical work has been amplified and almost all the library schools are paying heed towards this important task but the financial constraints, lack of lab facilities, scarcity of trained lab staff, problems of loadshedding, etc. are some identified hurdles in attaining the target.

\section{Conclusion}

The majority of the courses taught in all the library schools are composed of theory and practical. The theorypractical ratio varies from course to course and from school to school. Although due to the demand, some of the courses have been bifurcated into theory and practical but there is no proper ratio of credits and marks between the two, nor do they have separate passing heads. The curriculum designed by HEC, indicates ratio between theory and practice but either the universities are not practicing the HEC curriculum or if practicing, they do not follow the standard ratio of HEC. The practical training of any course is, no doubt, applied in the profession but to strengthen the professional knowledge and to understand the philosophy of the subject, theory courses also deserve equal importance. Without apprehending and grasping the subject matter and exhibiting command on the roots of the text, better professional services cannot be rendered. Similarly, one cannot deny the importance of theory courses in a profession as general opinion is that the philosophical and fundamental knowledge should continue to be imparted.

Since Library and Information Science is a professional discipline which focuses, besides theoretical and philosophical approaches, more on practical training. As far as practical courses are concerned, the professionals have different point of views with respect to the implementation of those courses in their profession. Those who have got chance to apply/implement the knowledge of such courses in their profession, declare the courses superb whereas those who could not get an opportunity, consider the courses unsuitable to be offered. The courses taught along with practical training and assignments have positive and useful impact in profession. Certain courses which are only theoretical-based enrich the enlightened and logical vision of the subject whereas those which are practical-based have implementation in running the routines and different administrative and technical operations of the library. The practical training imparted in the courses of Classification, Cataloguing, Reference Sources and Services, Bibliography, ICT, Digital Libraries, etc. is highly useful in the profession so they suggested not to only continue these trainings but should also expand to the use of modern techniques and equipment. To produce efficient, competent, updated and capable reference librarians, the research reveals that almost all library schools are paying special attention to the course of reference sources and services and besides theoretical concepts, practical work is also taken into consideration. The researcher identified certain courses whose practical training is almost not being applied in the profession. Of such courses, on the top are Indexing and Abstracting.

\section{References}

Haider, S. J. (2006). Teaching of cataloging and classification in Pakistan. Cataloging\& classification quarterly, 
43. 53-65.

Mahmood, K. and Khan, M.A. (2007). ICT training for LIS professionals in Pakistan: a needs assessment. Program. 41(4). 418-427.

Mahmood, K. (2003). A comparison between needed competencies of academic librarians and LIS curricula in Pakistan. The electronic library, 21(2).99-109.

Mahmood, K. and Sharif, A. (2001).Impact of computer training on professional library activities in Pakistan. Information Development, 17(3).173-177.

Malik, Amara, Ameen, Kanwal (2010). Effectiveness of library practicum: perceptions of LIS graduates in Pakistan. Library Review, 59(8). 573-584.

Shahid, Syed Muhammad and Singh, Joginder (2010). Changing needs of LIS curricula in India. Library philosophy and practice (e-journal) retrieved on 5-12-10.

Ullah, Midrar; Ameen, Kanwal; Bakhtar, Salman (2010). Professional activities, needed competencies and training needs of medical librarians in Pakistan. Education for information. 28(2-4). 115-123. 